\title{
Behavior Therapy and Modelo Latinoamérica; Assembling and Demarcating Psychology in Colombia
}

\section{Terapia del Comportamiento y Modelo Latinoamérica; ensamblando y demarcando la psicología en Colombia}

Envio 26/01/2014 | Revisión 26/07/2014 | Aceptación 27/07/2014

\author{
FREDY MORA-GÁMEZ* \\ Grupo de Estudios Sociales de la Ciencia, la Tecnología y \\ la Medicina, Universidad Nacional de Colombia ** \\ Group of Science, Technology, and Knowledge, \\ University of Leicester, UK
}

doi:10.11144/Javeriana.upsy13-5.btml

Para citar este artículo: Mora-Gámez, F. (2014). Behavior Therapy and Modelo Latinoamérica; Assembling and demarcating psychology in Colombia. Universitas Psychologica, 13(5), 1919-1930. http:// dx.doi.org/10.11144/Javeriana.upsy13-5.btml

* famorag@unal.edu.co,famg1@le.ac.uk

** This work is a modified and reviewed version of the first chapter of the graduate thesis Colombian Psychology: Knowledge, technique and expertise, reconstructions from Science and Technology Studies by Fredy Mora-Gámez as partial fulfilment for the title of Magister en Estudios Sociales de la Ciencia, at Universidad Nacional de Colombia,August, 2012. Special thanks to ASCOFAPSI, COLPSIC and the DIB for partially funding this research.

\begin{abstract}
A B S T R A C T
The set of psychological techniques known as Behavior Therapy is reframed as a sociotechnical device and its circulation from the US to Colombia in the 1970s is reconstructed. The circulation of Behavior Therapy is described in academic spaces such as Universidad Nacional de Colombia and Universidad Javeriana. The possibility of Behavior Therapy as a Boundary Object as a mean for demarcation from psychiatry, and as a way for promoting and mobilizing scientific discourses about subjectivity. Thus, a relation between the training guidelines for psychology curricula known as Modelo Latinoamérica and the assemblage of Behavior Therapy is outlined. Finally, some considerations for future interdisciplinary research on the history of psychology are proposed.

Keywords

history of psychology; Colombian psychology; psychological technologies; boundary objects; science and technology studies
\end{abstract}

\section{RESU MEN}

El conjunto de técnicas psicológicas conocido como Terapia del Comportamiento es replanteado como un dispositivo sociotécnico y se realiza una reconstrucción de su circulación desde EEUU hacia Colombia en los años 70. Posteriormente, se describe la circulación de la Terapia del Comportamiento en espacios académicos como la Universidad Nacional de Colombia y la Universidad Javeriana. Adicionalmente se discute la posibilidad de entender la Terapia del Comportamiento como un Objeto-Frontera, un medio para la demarcación con respecto a la psiquiatría, y una forma de promover y movilizar discursos científicos sobre la subjetividad. De esta manera, se delimita una relación entre los lineamientos de entrenamiento para currículos en psicología conocidos como Modelo Latinoamérica y el ensamblado de la Terapia del Comportamiento. Por último, se ofrecen algunas consideraciones para futuras investigaciones interdisciplinarias en el campo de la historia de la psicología.

Palabras clave

historia de la psicología; psicología colombiana; tecnologías psicológicas; objetofrontera; estudios sociales de la ciencia y la tecnología 
Behavior modification techniques based on laboratory experiments were widely circulated in the US since the 1920s. For instance, Cover Jones (1924) implemented classical conditioning techniques as Direct Conditioning and counterconditioning for reverting learned fears in children. Likewise, the manual written by Watson (1928) entitled Psychological Care of Infant and Child made him receive a prestigious prize given by the American Society of Parents. In the same way, after the publication of The Behavior of the Organisms: an experimental analysis in 1938, Skinner developed a protocol for training pigeons to guide bombs towards German targets by shaping response sequences through operant conditioning; however, it was only after World War II, when behavior modification techniques were widely unfolded because of a techno-scientific turn, consisting of a growing interest in developing technological tools out of experimental knowledge, in some of their representatives (Capshew, 1993).

Despite different practical problems of the implementation of behavior modification techniques in different settings (Reppucci \& Saunders, 1974), such devices were widely recognized for (a) the underlying assumptions of their configuration regarding the positivistic dominion of behavior (Moxley, 2006), (b) the possibility of technological control of human behavior, and (c) the primacy of effectiveness and the role of behavioral engineering (see Skinner, 1948). As Altus and Morris (2004) have pointed out, those assumptions were enthusiastically outlined by Skinner in the novel Walden Two, which narrates the story of a scientifically organized and planned society. Interestingly, these assumptions about human behavior were not emphatically confronted until the 1970s after the publication of Beyond Freedom and Dignity (Skinner, 1971). About Skinner's book on liberty and other algid political terms in the US, Noam Chomsky strongly claimed:

"A close analysis shows that the appearance is misleading. Skinner is saying nothing about freedom and dignity, though he uses the words 'freedom' and 'dignity' in several odd and idiosyncratic senses... as to its social implications, Skinner's science of human behavior, being quite vacuous, is as congenial to the libertarian as to the fascist" (Chomsky, 1971).
Even though behaviorism promoters might have claimed that their technologies and explanatory models were free from political interests, the main confrontational issues of their works precisely addressed politics and assumptions on human nature comprised in their narratives and procedures. Despite the 1970s confrontations, behavioral assumptions about human nature and behavior modification techniques had already been mobilized in different arenas against psychoanalytical approaches in North America.

\section{US circulations of Behavioral techniques: the case against Psychoanalysis}

Behavior therapist Andrew Salter, a former student of Clark Hull and a partner of Kazdin, suggested that hypnotic states could be better explained from classical conditioning experimental techniques; his book: What is Hypnosis? (1944) presented a major claim about the lack of scientific proofs in psychoanalytical and psychiatric approaches, likening their techniques to those implemented by mentalists and magicians. In contrast, Salter claimed that classical conditioning techniques could be used to modify even the most established habits, and that hypnosis was not a mind control activity but a technique better explained with Pavlovian categories (Salter, 1944, 1961).

But the above tension was only the first of several others in a crusade against the so-called pseudo-scientific psychologies by behaviorists. The Case against Psychoanalysis (Salter, 1952) consisted of one of the most intense divergences between Psychoanalysis and Behaviorism in North America. In a provocative way, Salter analyzed several Freudian concepts based on 388 references extracted from the psychoanalytic literature; he emphasized the tendency of Freud and his disciples to present "... evidence, which is less than nil..." (Salter, 1952, p. 30) Moreover, Salter claimed in this book: "Whenever a psychoanalyst has a fact he can't explain, he modifies it with a hypothesis he can't prove" (Salter, 1952, p. 58). This book was one of Salter's Best-seller pieces and was widely circulated among the psychological community of the US. 
In the upcoming 1960s and 1970s, psychologists Ayllon and Azrin (former students of Skinner) Kazdin, Yates and others were developing and promoting different techniques based on classical and operant conditioning. Some of those techniques were quite successful and well-used techniques for fears and phobias, self-regulation techniques for anxiety and token economies for motivational systems (O'Donohue, 1998; O'Donohue \& Krasner, 1995; Wolpe, 1973). This last procedure was especially implemented in psychiatric hospitals and prisons by Indiana University researchers, Ayllon and Azrin (1965) and other health institutions (Ayllon \& Michael, 1959).

By the end of the sixties, behavioral techniques were the main guidelines for Behavior Therapy (Watts, 1975). Thus, a new black box (see Woolgar, 1981; Latour, 1986) and a sociotechnical device (Bijker \& Law, 1994) named Behavior Therapy (henceforth BT) consisted of an assemblage of classical and operant conditionings, laboratory experiments, naturalistic assumptions about behavior and a positive dominion on subjectivity (Moxley, 2006), which effectiveness could be translated in measures among a period of time. Subsequently, BT spread along US universities in a considerable way by the end of the 1960s (American Psychological Association [APA], 1967; Brayfield, 1965). Therefore, most of the recognized training centers for psychologists should impart experimental psychology and BT promoting the use of experimentally based techniques; a new expert in psychological therapies derived from experimental data had also been co-produced (see Jasanoff, 2004) along with BT, this is, the behavior therapist.

The new form of therapeutic expertise and its behaviorist discourse had already demanded effectiveness from other accounts of human behavior like Psychoanalysis in the late 1950s. Similar ideas of effectiveness had also been promoted by the APA through the Boulder model in 1945 (Frank, 1984) and Vail model in 1973 (Donn et al, 2000). In those models, scientific-practitioners psychologists should design effective interventions using psychological scientific knowledge to solve different problems in professional spaces. A deeper analysis of that resemblance might stress the relation between BT and psychological training in the US, but the plausible connection outlined up to this point makes understandable why BT spread through different localities in the US, until it reached other countries in the American continent.

BT at Universidad Nacional de Colombia

During the ongoing assemblage of BT in the US by Skinner, Salter, Ayllon, Azrin and others (Miltenberger, 2008; O’Donohue, 1998) in the late sixties, Ardila, a Colombian psychologist from Universidad Nacional received general training in behavioral techniques during his doctoral training at University of Nebraska (personal record, Ardila, 2010). Ardila returned to Colombia and established an alliance with the International Union of Psychological Science (IUPsyS) in 1969 supported by the Colombian Federation of Psychology (López, Pérez-Acosta, Hurtado, Gamboa, \& Bustamante, 2006). By 1970, Ardila was already the director of the Department of Psychology at Universidad Nacional where he stayed for almost two years.

About the situation of the Department in 1970, in a recent autobiography, Ardila claimed that BT : "... had a huge impact on clinical psychology mainly ruled by psychoanalysis in Colombia and other nearby countries....Behavior Therapy had the virtue to promote the psychologist from a simple assistant of psychiatrists towards an autonomous exercise of his profession, using an experimental technology to approach clinical problems, which was unknown by psychiatrists". About the inclusion of BT topics and learning courses in the 1971 curriculum at Universidad Nacional, Ardila also stated: "It was said that experimental psychology exclusively addressed the study of rats, but we could demonstrate the usage of that knowledge and methodology also in humans" (personal record, 2010).

It seems that the mobilization of BT at Universidad Nacional de Colombia was mainly carried out in curricula and administrative decisions allowing a new form of expertise to mobilize in the academic institution. Despite the absence of references to BT in the curriculum of 1968, a course on Técnicas de Terapia Psicológica (Psychological Therapy Techniques) and another course on Psicología del 
Aprendizaje (Psychology of Learning) were approved on November $12^{\text {th }}, 1970$ for the next academic year (Facultad de Ciencias Humanas, 1970a). Then, the curriculum of 1971 already included both courses and BT was a module of Técnicas de Terapia Psicológica (Facultad de Ciencias Humanas, 1972). It seems that the mobilization of BT was jointly made with experimental psychology courses on classical and operant conditioning.

Whilst curricula changes were being discussed, the displacement of psychodynamic psychiatry from the Department of Psychology was also taking place. For instance, one of the staff training plans designed by the program director in October $6^{\text {th }} 1970$ indicates two positions for professors who could travel to the US to be trained in Behavior Therapy in the upcoming year (Facultad de Ciencias Humanas, 1970b). Likewise, Ardila as the director of the Department of Psychology emitted an internal communication in October $8^{\text {th }}, 1970$ asking the Vice-chancellor to transfer the psychiatrist Eduardo Laverde to the Faculty of Medicine arguing "[...]there will not be any more courses for him in the next semester" (Universidad Nacional de Colombia, 1970). With regard to this, Ardila said: "Psychiatrists were training us [psychologists] to do something we would never do in our practice, for example psychotherapy, because psychologists were exclusively in charge of assessment and evaluation using tests, and we were not going to do therapy in base of that training" (Personal record, Ardila, 2010). Therefore, the circulation of BT techniques was useful for promoting a non-medical but still naturalistic approach to subjectivity. As José Antonio Sánchez suggested about the events at Universidad Nacional: "[...] Behavior Therapy possessed the ideal properties of a techno-scientific tool because of its experimental basis, its proven effectiveness and its social relevance [...] that is why we told students about it...." (Personal record, Sánchez, 2010)

In a wider way, BT was strategically and explicitly circulated by its promoters in the second volume of Revista Latinoamericana de Psicología (RLP). In this regard, the RLP had recently been inaugurated in 1969 by Ardila, its chief editor (See Gallegos, 2010; Gómez-Morales, Jaraba-Barrios,
Guerrero-Castro, \& López-López, 2012). For the 1970 volume of RLP, psychologists such as A. J. Yates (University of Western Australia), R. M. Suinn (Colorado State University, USA) and R. Lieberman (National Institutes of Health, USA) published different papers exploring various aspects of BT like its definition, its uses in children and mental patients. All of these articles were translated into Spanish and the same number comprised the description of different academic events to be held regarding $\mathrm{BT}$, some existing associations on $\mathrm{BT}$, and a few BT books reviews made by Ardila and Castro, one of his students at Universidad Nacional. Thus, the techno-scientific character of BT would also be unfolded among other academic scenarios like Universidad Javeriana.

\section{BT at Universidad Javeriana, confrontations and mobilizations}

Some years before the arrival of BT to the Jesuit institution, the Faculty of Psychology had recently been established in 1968. By then, the node mainly composed by psychoanalytic psychiatrists, some philosophers with an interest in psychology and a few psychologists had already evidenced confrontations regarding the therapeutic expertise. About this, Álvaro Jiménez, a Jesuit philosopher and theologian who had been granted with a master's degree in experimental psychology in 1963, wrote an article in 1967 describing the situation of psychology in which he argued:

"In the Colombian public opinion there is a deformed image of the profession of psychologist. A lot of people, even with a high cultural level, think that this new professional is a sort of magician or wizard, who only lacks a turban, a crystal ball and the cards to tell the fortune. In social meetings, everybody speaks about the psychologist as a person who is capable of reading minds and knowing a person from the inside by just 'looking'. In the best-case scenario, psychology is considered a female course of study which provides certain pride, especially suitable for polite and high-class girls, as well as excellent opportunities to get a good boyfriend at the 
university..."1 (suspension marks originally written by Jiménez, 1967)

What Salter had claimed about psychoanalytical approaches in the US, was now part of a social imaginary of psychology in Bogotá. Besides this particular appreciation, Jiménez also claimed that psychiatrists considered the psychologist as a "second level professional" or a "laboratory technician" who was not trained to collaborate with them as an equal but to "serve" them by the implementation of tests; moreover, Jiménez asserted that the very possibility of a psychologist performing psychotherapy made his colleagues worry and some of them to oppose this possibility.

During 1967 and 1968, Jiménez wrote several letters to directors at Javeriana, asking for permission to offer courses like "Experimental designs in Psychology" and "Psychotherapy", some of them to be taught by José Antonio Sánchez. In a letter written on November 30, 1968 to Jesús Arroyo, a guest professor who was not in Colombia at that moment, Jiménez pointed out some tensions regarding psychotherapy with Alvaro Villar Gaviria, a renamed psychiatrist in the late 1960s who explicitly favored psychoanalytical techniques (See Villar Gaviria et al., 1978); such tensions took place during the VIII National Congress of Psychiatry. Jiménez said: "During his presentation, Dr. Villar obviously made some critics against our Faculty. It is not surprising [...] as you see, they [the students] come back with

1 En la opinión pública colombiana prima una imagen muy deformada de lo que es la profesión del psicólogo. Mucha gente, aún de cierto nivel cultural, se imagina que el nuevo profesional es una especie de mago, de hechicero al cual solo le falta el turbante, la bola de cristal y las cartas para adivinar el porvenir. En las reuniones sociales se habla del psicólogo y con el psicólogo como la persona capaz de leer el pensamiento y con solo su mirada conocer el interior de las personas. En el mejor de los casos se considera como 'una carrera muy femenina' que da cierto prestigio, especialmente apta para niños elegantes y de buena sociedad, que brinda oportunidades nada despreciables de conseguir un buen novio en la Universidad...".

Los psiquiatras, por su parte y con raras excepciones, consideran al psicólogo como un profesional de segunda categoría, así como un técnico de laboratorio que se forma no para colaborar con ellos en pie de igualdad como colega, sino a lo más para servirles en la aplicación de test o para trabajos sencillos en el campo escolar principalmente. La sola posibilidad de que un psicólogo pueda alguna vez practicar la psicoterapia escandaliza y preocupa a nuestros colegas. Algunos hacen una abierta oposición por esta causa. the 'fever' of psychotherapy, do not be anxious, after calming down we shall study the situation here and determine what to do"

In 1971, Jiménez was substituted by José Antonio Sánchez, so BT and other experimental courses were brought into the curriculum; the First Colloquium on Learning and Behavior Therapy was carried out in 1972 with the participation of José Antonio Sánchez, pointing out the relevance of techniques other than psychoanalytic ones (Ballesteros, 2005 cited by López et al., 2006) About this event, Sánchez (personal record, Sánchez, 2010) argued that psychiatrists and philosophers were invited so that they could learn about scientific psychology and get interested in it. Nevertheless, an interview provided by a psychologist who graduated from Universidad Javeriana during the seventies suggests something different:

"At that time, many behaviorist psychologists came here and promoted the model with a sort of fanaticism; many of us believed Behaviorism was kind of a revealed truth and some of my colleagues followed the line of Ardila at Universidad de los Andes; when they realized that many of the promises made were false, it was too late for some of them, who were even accused in the media of carrying out unethical experiments on humans". (Anonymous record, 2011)

The evident deception in these words refers to the partial success of Behavior Analysis through BT at Universidad Javeriana; in spite of this initial success, the upcoming events were interpreted by this interviewee as the confirmation of a "false promise". This relative success of Behaviorism, and its legitimating device, was reconstructed by Maggui Gutiérrez (2010), a former student and professor at Universidad Javeriana, in the following words:

"[...] the students reported that, up to that moment, in the Faculty, the requirements for psychology to be considered as a science had not been applied to the field of Clinical Psychology. A few of them migrated to

2 "En la ponencia del Dr. Villar, naturalmente hubo sus 'guamas' contra nuestra Facultad. No me extraña [...] como ves, [los estudiantes] vuelven con la 'cantinela' de la psicoterapia, no te afanes ni te preocupes. Aquí estudiaremos con cabeza fría que debemos hacer". 
the Universidad de Los Andes, a bastion of the 'true psychological science'".

The circulation of Behavior Analysis concepts through BT was actually very successful inasmuch some students from Javeriana moved to Universidad de los Andes. This migration of students occurred between 1972 and 1973, before some modifications were made to the curriculum at Javeriana after the requests of some students (Peña 1993, p. 46). By 1972, Ardila and Castro were already in charge of a new psychology program with an experimental emphasis at Universidad de los Andes.

During the forthcoming years, Ardila and Sánchez moved through different universities located in Bogotá such as Universidad Santo Tomás and Universidad Católica de Colombia. Thereby, Learning and Behavior Therapy modules and animal behavior laboratories were established in most of those programs during the late seventies and the early eighties, so several psychology programs were also founded (Ardila, 1985). Those new think tanks in different universities definitely promoted BT, its social projects and experimental discourses about human behavior. Moreover, the consolidation of a master's program in 1976 at Universidad Santo Tomás and the possibility for physicians and psychiatrists to apply to such graduate programs so that "different professions could learn about the findings of psychology as a useful discipline" (personal record, Ardila, 2010) suggest the plausibility of this account.

\section{BT: a sociotechnical device for demarcation}

In the United States, BT was used to publicly question psychoanalysis and its variations in terms of effectiveness, validity and scientific rigor. In Colombia such rhetoric of effectiveness was important in the tensions with psychoanalytical promoters, but local psychologists also translated (in the sense proposed by Callon, 1986; Latour, 1986, 1999) BT as a device to demarcate psychiatry and psychoanalytical approaches. The legitimating relation between BT promoters and the US as a major intellectual centre of Colombia and Latin
America in the 1970s played an important role in this dynamic.

During the same period, different associations were established around the main topic of reflection: BT. For example, in 1971 the Colombian Federation of Psychology (FCP) proposed a law project to the Congress with the aim of recognizing psychology as a scientific discipline and a practice in Colombia; Ardila, Sánchez and others wrote the project document with a particular "experimental" and "behaviorist" rhetoric having an important place:

"The main working areas [of Psychology] comprise: (1) basic and applied research, (2) University teaching, (3) psychological diagnosis, (4) psychological prophylaxis (5) Selections and orientation for individuals and groups (6) Behavior analysis of the individual as part of the group (7) Behavior Modification (8) solving individual and group adjustment problems." (Ardila, 1975) Plan quinquenal de la psicología 1970-1975.

Revista latinoamericana de Psicología. 7, 3

It was not until 1983 that the first Law of Psychology was approved in Colombia, due maybe to a typical delay in this kind of procedure or because of the public and academic space that psychological communities had recently achieved. Whatever the reason, the resemblance between the law project from 1971 and the approved law in 1983 is remarkable:

"Some functions of a psychologist are the usage of psychological methods and techniques with the following purposes: basic and applied research, teaching, psychological diagnosis, psychological treatment, orientation and professional selection assistance, group and individual behavior analysis and modification, and psychological prophylaxis." (República de Colombia, 1983).

3 "Las principales áreas de trabajo (del psicólogo), a saber (1)Investigación básica y aplicada, (2)Docencia en nivel universitario, (3) Diagnóstico psicológico, (4)profilaxis psicológica, (5) Selección y orientación a individuos y grupos (6) Análisis del comportamiento del individuo dentro del grupo (7) Modificación del comportamiento (8) Solución de problemas de ajuste individual y grupal." (Ardila, 1975) Plan quinquenal de la psicología 1970-1975. Revista Latinoamericana de Psicología, 7(3)". 
The 1971 law project consisted of a plausible strategy to promote the idea of an independent discipline and its expertise; even though some of the members of FCP were neither therapists nor behaviorists, the scientific discourse assembled into BT and Behavior Analysis was a useful rhetorical tool to print such ideas in academic and legal settings. Nevertheless, if we overlook the usual delays in the approbation of Laws in Colombia, the late approval of the law suggests that other stabilizations were necessary, such as the mobilization in different applied scenarios, the foundations of different associations, the consolidation of scientific practices and the need for more professionals and experts in local scenarios promoted by the Education Minister through the Professional Practice Law of 1981.

In 1974, the First Latin-American Conference about psychological training was held in Bogotá and psychologists gathering psychologists and BT promoters from different countries. According to Ardila (2011) this important event was partially funded by the International Union of Psychological Science (IUpsyS) and UNESCO to promote a scientific-practitioner model based on the North American proposals for psychological training. Thus, Vail and Boulder models had now been assembled into a five-year program consisting of scientific training in experimental psychology, professional practices, and a degree thesis; this program was circulated as Modelo Latinoamérica, also called Modelo Bogotá (Ardila, 2011), which had an important influence on several local and international curricula (Gallegos, 2010).

BT and Modelo Latinoamérica

In the Latin American Conference held in 1974, four of the 22 presentations addressed clinical expertise from BT and Behavior Analysis, with six further presentations on the professional training of psychologists, which stressed the importance of the scientific validity of the techniques. Some of the main agreements of this event written up by Ardila, which were reviewed and approved by the participants concluded:

"Psychology is a science and a profession. The training of Latin-American psychologists must consider both as- pects; first of all, the psychologist is a Behavior scientist and then, a specialist in a certain method or technique" and "[...] scientific research is the only way to develop psychology and it is also a way to update the knowledge of the professor, the student and the professional. Scientific research in psychology must be promoted in Latin-American countries" (Gallegos, 2010).

Moreover, one of the main proposed actions in this Conference consisted of asking UNESCO for "... a more appropriate new classification of psychology, so that this discipline should be included as a natural science and "psychologists should participate in that classification”. (Gallegos, 2010, pp. 803-805)

The Colloquium at Universidad Javeriana and the Latin American conference were major events that circulated a scientific model for raising local communities of psychologists, and spaces of translation to promote a specific model (North American). These were determinant translations for the consolidation of important relations between Latin American psychological curricula and the US.

Correspondingly, the Latin American Association for Behavior Analysis and Modification (ALAMOC) was founded in Bogotá in 1975; this node gathered psychologists, teachers, physicians and other professionals (personal record, Ardila, 2010). The establishment of the Foundation for the Advancement of Psychology (FAP) in 1977 and the Colombian Society of Psychology (SOCOPSI) in 1978 were two other groups that exemplified the importance of BT in the field of academic psychology. Therefore, Colombian psychology, which was initially built around psychometrics and the study of subjective phenomena, had now been reconfigured after the incorporation of BT as a techno-scientific object, its experimental narratives and its naturalistic assumptions about human nature.

Similarly, the annual meetings of the Latin-American Congress of Behavior Analysis and Modification from 1975 to 1978, and the Interamerican Congress of Psychology of 1974 also suggest that massive transformations and mobilizations were occurring in other South American countries. In consistency, recent analysis (Gómez-Morales 
et al., 2012; Jaraba-Barrios, Guerrero-Castro, Gómez-Morales, \& López-López, 2011) have suggested that specialized journals such as Aprendizaje y Comportamiento (directed by ALAMOC) were circulated during the late seventies; meanwhile, Revista Latinoamericana de Psicología increased its number of articles.

Even though psychological expertise regarding tests and psychometrics had already been assembled in Colombia during the fifties and sixties (Ardila, 1967, 1971; Hernández-Vargas, Valencia-Lara, \& Rodríguez-Valderrama, 2003), it was perhaps the circulation of BT and its corresponding expertise which allowed psychology to demarcate itself from psychiatry at Universidad Nacional and Universidad Javeriana. The assemblage of BT was achieved through many academic events, associations, and publications focused on the topic, whilst a scientific-practitioner model was widely promoted in different curricula, as kind of a behavioral translation of Boulder and Vail models and later alterations, also called Modelo Latinoamérica or Modelo Bogotá. New psychologists who were trained under the new model and its resulting curricula were also meant to become scientific-practitioners who could contribute to the development of less developed countries, as Ardila and Castro (1973) had suggested previously about the role of psychology in the implementation of development programs.

The circulation of experimentally constructed devices also resulted in the legitimation of experimental practices of psychologists. This new track shows itself in successful demands for unique training spaces (specialized laboratories), and the growing ability of psychologists to offer clinical expertise in a range of settings without the supervision or control of psychiatrists. In this sense, it is interesting that in the records of the professors' meeting regarding the curriculum changes from 1970 to 1972 at Universidad Nacional, there are not any discussions about the experimental validity of the techniques that took place; so, at least in the academic setting, those devices were already sealed black-boxes. (see Woolgar, 1981)

Lampland and Leigh Star (2009) define a Boundary Object as a device that, by circulating through the links of a network, permits translation between groups on either side of some boundary or demarcation. These objects have a relational property, which allows groups with different interests to communicate in quite effective ways about a common topic. In this case, BT allowed behavioral psychologists, psychiatrists and psychologists with other approaches to discuss and negotiate about a common ground: the therapeutic expertise. Thus, beyond demanding effectiveness from psychoanalytical approaches like the US case, BT actually allowed psychologists to stabilize and negotiate a legitimate place in academic and labor distribution as experts in psychological interventions, which were designed in base of experimental findings.

The reconfiguration of the sociotechnical network was mobilized into other spaces. For example, the claim of a positive dominion over human behavior assembled in BT transcended academic and therapeutic scenarios, and was extended by its promoters to different arenas like national development programs (see Ardila \& Castro, 1973). About this relation with national development, Pulido (2006) has noted the correspondence between the notion of control implied in psychological discourses, the ideology of development and the construction of identities of Colombian citizens. Other claims regarding the assumptions of BT comprised its implementations in prisons in 1975, where the notion of control caused an important media exchange regarding the implementation of BT at the prison El Buen Pastor in Bogotá in 1975 (Gutiérrez, 1975), and an intense confrontation had place between sectors of the Catholic Church, instances of the government and promoters of BT at Universidad de Los Andes (Mora-Gámez, 2013).

\section{Some conclusions}

Several chronological and historical reconstructions that provide an approach to the configuration of psychology in Colombia (Ardila, 1975; Ardila \& Pereira, 1975; Giraldo \& Rodríguez, 1997; Mankeliunas, 1980, 1993; Peña, 1993) are inherently based on perspectives of the history of science that comprehend such process as the result of cumulative 
efforts assuming a linear development of scientific practices. Those traditional accounts make the consolidation of scientific communities possible around an agreement on the structures of science (Merton, 1973). A good example of this is the tendency of traditional accounts of the history of psychology to establish the foundation of Colombian psychology around psychometrics (Jaraba-Barrios, 2013). Nevertheless, some authors from psychology and interdisciplinary scenarios find more relevant to employ emerging approaches that provide further descriptions of the social factors implied in the configuration of scientific knowledge (Danziger, 1979; Hacking, 1995; Lynch, 1994; Rose, 1996). Thus, the presented case tried to follow the latter perspective by emphasizing the socio-cultural character of psychology under the assumption that scientific facts and techno-scientific devices are also rhetorical artifacts. So, the description of translations and mobilizations makes possible critical, reflexive and situated analyses about local psychology, this is, a Second-Order Psychology (Brown \& Stenner, 2009) "which attempts to pursue the psychological across the complex, cultural and material forms that it takes" (p. 5).

As mentioned before, psychometrics has traditionally been addressed as the relevant expertise on which Colombian psychology was established. However, the events that occurred around the circulation and translation of BT in Bogotá were major and important reconfigurations in which clinical expertise mobilized the consolidation of a scientific community, in a wider sense than psychometrics had done before. Actually, if the term foundation is substituted by more dynamic and flexible concepts such as demarcation, the 1970s were the years in which major reconfigurations of local psychology took place through BT. As Jaraba-Barrios (2013) pointed out, the foundation of Colombian Psychology might be challenged by a different understanding of psychology as a social and local complex dynamic.

The demarcation of Colombian psychology was successful in various clinical psychology modules in different universities that still include BT as a historical background for psychology in the
US and Colombia. Whatever the case, Behavior Analysis is still well represented in the current Colombian academic scenario. This is important because the consolidation of behaviorist community in the particular case of Bogotá and other localities in Colombia also becomes a matter of socio-historical comprehension. In this sense, the complexities of the psychological community and its practices might transcend the theoretical confrontations among psychological approaches. In base of the connections presented, most of the reasons why Behavior Analysis and its subsequent variations still occupy a significant position in the Colombian psychological community nowadays are related to the socio-historical contingencies and mobilization strategies that were part of the assemblage of BT and Modelo Latinoamerica in Bogotá that began in the 1970s. These include the circulation of scientific discourse appealing to its technical effectiveness, the US - Latin America network that was spreading from the North, the political interest of BT promoters represented in a law project, the circulation of BT in publications and associations, and the establishment of a training model for scientific-practitioner psychologists like Modelo Latinoamérica, among others. Therefore, the behavioral narratives unfolded by BT became the accepted way to promote a scientific notion of psychology as natural science and scientific practice for professionals in different scenarios.

It might be relevant to track the uses of BT and its assemblage by different actors as well as the resulting identities in the experts themselves, the clients/users/patients. In other words the psychologization (See Pulido, 2006) of different forms of citizenship in various periods of time with regard to BT. In a more ambitious project for researchers in the histories of psychology, a sociotechnical approach to past and current psychological discourses/devices might provide useful insights on the relation between psychology and other social conglomerates, this means, the way similar sociotechnical devices based in naturalistic approaches to subjectivity have been used to construct narratives about different forms of citizenships and identities. 
An approach from Science and Technology Studies to psychological sciences and their history, as a comprehensive description of the reconfigurations and circulations of different sociotechnical devices of psychology, might be a challenging approach to be explored in the historical and current events of Latin-American sciences. Moreover, it could be one step, perhaps a fragmentary one (Klappenbach \& Pavesi, 1994, p. 449), towards a better understanding of the relation between science and society. This relation addresses not only the interaction between scientific communities and other social institutions, but also an ontological redirection that recognizes the social dynamics of scientific knowledge as a human activity; this also means a redirection in the comprehension of psychological knowledge, as something actually possible because of the social factors, which are inherent to its dynamic, instead of trying to reconstruct our historical contingencies as a set of disembodied ideas without any sort of social materiality.

\section{References}

Altus, D. E., \& Morris, E. K. (2004). BF Skinner's utopian vision: Behind and beyond Walden Two. Contemporary Justice Review, 7(3), 267-286.

American Psychological Association. (1967). (Report). American Psychologist, 22(3), 241-252.

Ardila, R. (1967). La psicología en Colombia. Revista Interamericana de Psicología, 1(4), 239-249.

Ardila, R. (1975). La historia de la Psicología en Colombia y el plan quinquenal 1970-1975. Revista Latinoamericana de Psicología, 7(3), 435-446.

Ardila, R. (1985). El análisis experimental del comportamiento en Colombia - Parte B. Revista Latinoamericana de Psicología, 17(3), 359-369.

Ardila, R. (2011). El mundo de la psicología. Bogotá: Manual Moderno.

Ardila, R., \& Castro, L. (1973). The role of applied psychology in the national development programmes in Colombia. International Review of Applied Psychology, 22, 65-75.

Ardila, R., \& Pereira, F. (1975). Psychotherapy in Colombia. Revista Interamericana de Psicología, 9(1-2), 149-163.
Ayllon, T., \& Azrin, N. (1965). The measurement and reinforcement of behavior of psychotics. Journal of Experimental Analysis of Behavior, 8, 357-383.

Ayllon T., \& Michael, J. (1959). The psychiatric nurse as a behavioral engineer. Journal of Experimental Analysis of Behavior, 2, 323-334.

Bijker, W. E., \& Law, J. (Eds.). (1992). Shaping technology/building society: Studies in socio-technical change. Cambridge, MA: MIT press.

Brayfield, A. (1965). Perspectives on APA (Report of the executive officer 1965). American Psychologist, 20(12), 1018-1027.

Brown, S., \& Stenner, P. (2009). Psychology without foundations. London: Sage.

Callon, M. (1986). The sociology of an actor-network: The case of the electric vehicle. In M. Callon, J. Law \& A. Rip (Eds.), Mapping the dynamics of science and technology (pp. 19-34). London: Macmillan Press.

Capshew, J. (1993). Engineering behavior: Project Pigeon, World War II, and the conditioning of B. F. Skinner. Technology and Culture, 34(4), 835-857.

Chomsky, N. (1971, December 30). Review of B. F. Skinner's beyond freedom and dignity. The New York Review of Books, 17, 18-24.

Cover-Jones, M. (1924). A Laboratory study of fear: The case of Peter. Pedagogical Seminary, 31, 308-315. Available at http://psychclassics.yorku.ca/Jones/

Danziger, K. (1979). The social origins of modern psychology. En A. Buss (Ed.), Psychology in social context (pp. 27-45). New York: Irvington.

Donn, J. E., Routh, D. K., \& Lunt, I. (2000). From Leipzig to Luxembourg (via Boulder and Vail): A history of clinical psychology training in Europe and the United States. Professional Psychology: Research and Practice, 31(4), 423.

Facultad de Ciencias Humanas. (1970a). Plan de estudios del programa de Psicología. Bogotá: Universidad Nacional de Colombia.

Facultad de Ciencias Humanas. (1970b). Plan de formación docente. Programa de psicología. Bogotá: Universidad Nacional de Colombia.

Facultad de Ciencias Humanas. (1972). Plan de estudios del programa de psicología. Bogotá: Universidad Nacional de Colombia. 
Behavior Therapy and Modelo latinoamérica; Assembling AND DEMARCATING PSYCHOLOGY IN COLOMBIA

Frank, G. (1984). The Boulder model: History, rationale, and critique. Professional Psychology: Research and Practice, 15(3), 417-435.

Gallegos, M. (2010). La primera conferencia latinoamericana sobre entrenamiento en psicología (1974): el modelo latinoamericano y su significación histórica. Psicologia, Ciência e Profissao, 30(4), 792-809.

Giraldo, B., \& Rodríguez, O. (1997) Historia de la psicología en Colombia: recuento de algunos de los eventos más significativos en los primeros 50 años de historia profesional. Revista de Historia de la Psicología, 18, 3-4

Gómez-Morales, Y., Jaraba-Barrios, B., Guerrero-Castro, J., \& López-López, W. (2012). Entre internacionalización y consolidación de comunidades académicas locales: sobre la Revista Latinoamericana de Psicología. Revista Colombiana de Psicología, 21(1), 97-110.

Gutiérrez, M. T. (1975). Intercambio de valores arbitrarios por valores morales en una cárcel de mujeres de Bogotá D. E. (Documento de tesis). Facultad de Psicología, Universidad de los Andes, Bogotá, Colombia.

Gutiérrez, M. I. (2010). La mirada de un devenir. Cuadernos de Psicología, 6(1).

Hacking, I. (1995). Rewriting the soul. History of the Human Sciences, 8, 107-107.

Hernández-Vargas, E., Valencia-Lara, S., \& RodríguezValderrama, J. (2003). De la sección de psicotecnia al laboratorio de psicometría: Seis décadas de algo más que medición psicológica en Colombia. Avances en Medición, 1(1), 6-16.

Jaraba-Barrios, B. (2013). Ardila y sus precursores: produciendo la tradición historiográfica de la psicología colombiana. Interamerican Journal of Psychology, 46(1), 147-157.

Jaraba-Barrios, B., Guerrero-Castro, J., Gómez-Morales, Y., \& López-López, W. (2011). Bibliometría e historia de las prácticas académicas locales: un esbozo a partir del caso de la psicología en Colombia. Avances en Psicología Latinoamericana, 29(2), 168-183.

Jasanoff, S. (Ed.). (2004). States of knowledge: The coproduction of science and the social order. London: Routledge.
Jiménez, A. (1967). La docencia de la psicología en la Pontificia Universidad Javeriana. Ponencia ante el VII Congreso Nacional De Psiquiatría. Manuscrito no publicado.

Jiménez, A. (1975, mayo 25).¿Hacia dónde va la psicología colombiana? El Espectador.

Klappenbach, H., \& Pavesi, P. (1994). Una historia de la psicología en Latinoamérica. Revista Latinoamericana de Psicología, 26(3), 445-481.

Lampland, M., \& Leigh-Star, S. (2009). Standards and their stories. How quantifying, classifying and formalizing practices shape everyday life. New York: Cornell University Press.

Latour, B. (1986). The powers of association. In J. Law (Ed.), Power, action and belief: A new sociology of knowledge? London: Routledge.

Latour, B. (1999). On recalling ANT. Actor Network Theory and After, 17, 93-95.

Lieberman, R. (1970). Terapia conductual de familias y parejas. Revista Latinoamericana de Psicología, 2(2), 161-182.

López, W., Pérez-Acosta, A., Hurtado, C., Gamboa, C., \& Bustamante, B. (2006). Análisis del Comportamiento en Colombia. Avances y Perspectivas. Avances en Psicología Latinoamericana, 25(1), 59. 69.

Lynch, W. (1994). Ideology and the sociology of scientific knowledge. Social Studies of Science, 24(2), 197-227.

Mankeliunas, M. V. (1980). Desarrollo de la psicología en Colombia y su ubicación como ciencia. En G. Aldana de Conde \& M. T. González (Eds.), La psicología iciencia social? (pp. 19-33). Bogotá: Pontificia Universidad Javeriana.

Mankeliunas, M. V. (1993). Desarrollo histórico. En R. Ardila (Comp.), Psicología en Colombia. Contexto social e histórico (pp. 43-66). Bogotá: Tercer Mundo.

Merton, R. K. (1973). The sociology of science: Theoretical and empirical investigations. Chicago: University of Chicago Press.

Miltenberger, R. (2008). Behavior modification: Principles and procedures. Belmont: Wadsworth CENGAGE Learning.

Mora-Gámez, F. (2013). Ensamblando el control: tecnologias psicologicas de rehabilitacion en la carcel 
de mujeres El Buen Pastor. In O. Restrepo (Ed.), Ensamblado ciudadanías. Bogota: Editorial CES.

Moxley, R. A. (2006). B. F. Skinner's other positivistic book: Walden Two. Behavior and Philosophy, 34, 19-37.

O’Donohue, W. (1998). Learning and behavior therapy. Boston: Allyn and Bacon.

O’Donohue, W. T., \& Krasner, L. E. (Eds.). (1995). Theories of behavior therapy: Exploring behavior change. Washington DC: American Psychological Association.

Peña, T. E. (1993). La psicología en Colombia: historia de una disciplina y una profesión. In C. E. Vasco, D. Obregón \& L. E. Orozco (Coords.), Historia social de la ciencia en Colombia. Ciencias sociales (Vol 9, pp. 95-179). Bogotá: Colciencias.

Pulido, C. (2006). Produciendo trabajadores modernos: conocimiento psicológico y el mundo del trabajo en el sur. Universitas Psychologica, 6(1), 27-37.

Reppucci, N. D., \& Saunders, J. T. (1974). Social psychology of behavior modification: Problems of implementation in natural settings. American Psychologist, 29(9), 649-660.

República de Colombia. (1983) Ley 58 de 1983 "Por la cual se reconoce la Psicología como una profesión y se reglamenta su ejercicio en el país"

Rose, N. (1996). Inventing our selves. Cambridge: Cambridge University Press.

Salter, A. (1944). What is hypnosis? Studies in conditioning. New York: Richard R. Smith.

Salter, A. (1952). Conditioned reflexes therapy. London: Allen \& Unwin.

Salter, A. (1961). Conditioned reflex therapy. Manila: Wellness Institute, Inc.

Skinner, B. F. (1938). The behavior of the organisms: An experimental analysis. Cambridge: B. F. Skinner Foundation.

Skinner, B. F. (1948). Walden II. Indianapolis: Hackett Publishing Co.

Skinner, B. F. (1971). Beyond freedom and dignity. New York: Bantam Books.

Suinn, R. M. (1970). Desensiblización: nuevos procedimientos. Revista Latinoamericana de P s i . cología, 2(2), 129-136.

Universidad Nacional de Colombia. (1970, octubre 7). Memorando de la dirección del programa de Psicología a la dirección del programa de Medicina. Bogotá: Facultad de Ciencias Humanas.

Villar Gaviria, A. (1978). Desarrollo de la psicología en Colombia: aporte para el estudio de su historia. In F. Chaparro \& R. Sagasti (Cpmps), Ciencia y tecnología en colombia (pp. 221-250). Bogotá: Instituto Colombiano de Cultura.

Watson, J. B. (1928). Psychological care of infant and child. New York: Norton \& Co.

Watts, M. (1975). B. F. Skinner and the technological control of social behavior. The American Political Science Review, 69(1), 214-227.

Wolpe, J. (1973). The practice of behavior therapy. Elmsford, NY: Pergamon Press.

Woolgar, S. (1981). Interests and explanation in the social study of science. Social Studies of Science, 11, 365-394.

Yates, A. J. (1970). La definición de terapia conductual. Revista Latinoamericana de Psicología, 2(2), 113-121. 